Forthcoming in Mader, P., Mertens, D. and van der Zwan, N. (2019) International Handbook of Financialization. Abingdon: Routledge.

\title{
Financialization as mathematization: The calculative and regulatory consequences of risk management
}

Nathan Coombs, Arjen van der Heide

\begin{abstract}
Financialization is commonly understood as the increasing centrality of financial actors and logics in the economy. However, building upon literature which relates financialization to the mathematization of financial valuation practices, this chapter argues that the banking sector was itself financialized since the 1980s. Our historical overview of the changing nature of banking traces the thread running from the Black-Scholes options pricing formula through to Value-at-Risk modelling and Collateralized Debt Obligation valuation. We explore the calculative and regulatory consequences of these risk management techniques and how they allowed large volumes of risk to be removed off banks' balance sheets and regulatory capital minimized, with deleterious results for financial stability.
\end{abstract}

\section{Introduction}

That financial markets play an increasingly important role in capitalist economies is beyond doubt. Today large firms often turn to bond markets rather than banks to finance their operations; and many banks focus on securitizing and trading assets instead of investing in the traditional sense. Over recent decades the notion of financialization has been adopted by critically minded scholars seeking to relate these trends to problems such as declining economic productivity, rising inequality and heightened financial fragility (Alvarez, 2015; Stockhammer, 2004; Tridico \& Pariboni, 2018). While rival explanatory lenses have also been proposed (most notably, globalization and neoliberalism), the unique contribution of 
financialization scholars is to see these problems as predictable symptoms of the increasing share of economic pie being siphoned off by rent-extracting financial actors since the 1970s.

What enabled the financialization process? The literature offers various suggestions: from the rise of the corporate shareholder value orientation (Froud et al., 2000; Lazonick \& O'Sullivan, 2000) to the decline of capital controls and international trade liberalisation (Arrighi, 1994; Epstein, 2006). Despite their differences, these accounts tend to focus on the extra-financial reasons why firms, states and households have been progressively co-opted into financial logics and mechanisms. But is charting the changing balance of power between financial and non-financial forces sufficient to understand the shift? A new wave of studies insist that it is not and stress the importance of attending to changes internal to finance (Besedovsky, 2017; Carruthers, 2015; Chiapello, 2015; Lengwiler, 2016; Poovey, 2015). In particular, they identify the rise of financial mathematics as playing a key role in upending finance's traditional role in the economy. These authors thus understand finance's changing calculative practices not simply as innovations within a stable field but as a profound shift in what finance does and what it is for.

This chapter follows that theoretical lead, albeit with caveats. For there is a danger that when these studies emphasise the significance of financial mathematization that they imply a certain inevitability about the consequences of increasing technological complexity. If seen as a result merely of intensified quantification, financialization then comes to seem like just the natural culmination of Weberian techno-scientific rationalization. In contrast, this chapter argues that while calculative innovation was a key driver of changes within finance, contingent regulatory decisions played an equally essential role. Moreover, we contend that these changes are sufficiently profound to themselves be seen as a process of financialization even in the absence of references to their effects in the so-called 'real' economy. 
We demonstrate that this is the case through a historical overview of the rise of risk management in the banking sector. The narrative is not entirely new. For instance, portfolio theory and the Black-Scholes option pricing formula have been identified as a pivotal developments in the 'financialisation of financial matters' (Chiapello, 2015: 14). Scholarship has also analysed the role of financialized regulatory approaches in constructing the fragile market-based banking model (Gabor, 2016; Gabor \& Ban, 2016; Hardie \& Howarth, 2013). Hitherto lacking, however, has been the thread that unites the story's key 'moments'. We fill that gap by identifying the Black-Scholes-Merton (BSM) formula, Value-at-Risk (VaR) modelling and Collateralized Debt Obligation (CDO) valuation as three crucial, cumulative developments in financial modelling which allowed risk to be moved off-balance-sheet and regulatory capital minimized. We also draw attention to how, from the 1990s onwards, regulators played an active role in pushing market actors towards adopting the risk management strategies pioneered and promoted by leading firms. That this would culminate in the most damaging financial crisis since the Great Crash of 1929 provides the denouement to the story, with still ambiguous repercussions in the post-crisis era.

The discussion begins by situating work on calculative practices in the wider literature on financialization. We argue that understanding financialization as mathematization allows literature in the social studies of finance, thus far disconnected from financialization studies, to be incorporated into the research agenda. The following section provides a historical overview of the rise of financial risk management, focusing on how portfolio theory and the BSM formula established the equivalence of 'value' and 'risk' underpinning VaR modelling. The next section addresses how the Basel Committee on Banking Supervision enthusiastically embraced the new science of financial risk management with the 1997 Market Risk Amendment to Basel I and Basel II in 2004. The story is completed in the final section which turns to how securitization, particularly CDOs, 
provided banks with an opportunity to move risks off their balance sheets and reduce their regulatory capital while also opening up profitable arbitrage opportunities. The conclusion reflects on the ambiguous fate of risk management in the aftermath of the global financial crisis. On the one hand, very little has changed: derivatives continue to circulate in large volumes, securitization quickly recovered in the United States, and the use of VaR-like techniques for calculating firms' regulatory capital remains firmly entrenched. On the other, public authorities are subjecting these techniques to ever greater oversight, questioning the neoclassical principles underpinning financial risk management, and developing their own models for seeing and controlling the complex financial system they helped bring into being. Thus, while significant attempts at regulatory reform have been made, the calculative infrastructure and regulatory incentive structures set in place by the banking sector's financialization remain mostly unperturbed.

\section{Calculative engines of financialization}

Social science involves a search for concepts that can help us follow the historical pathways leading to the predicaments of the present. A particularly challenging puzzle in recent decades has been how to characterise Western capitalist economies after the decline of the post-war Keynesian settlement. That no consensus has been reached points to the difficulty of making generalisations broad enough to serve as a powerful explanatory lens while not over-extending their reach (Venugopal, 2015). The notion of financialization is no exception. Although serving to concentrate minds across the disciplines, it has only done so through tolerating a certain conceptual liberalism, with overviews of the literature identifying at least seventeen separate meanings attached to the term (Lee et al., 2009: 729). Another concern raised by scholars is that, paradoxically, this literature often has "relatively little to say about finance per se" (Christophers, 2015: 191). As noted by Besedovsky (2017: 5), although a huge variety of theoretical concerns and empirical foci, macro-, meso- and micro-level in orientation, are captured by different studies of financialization, few address the epistemic implications of 
finance's changing calculative practices. The observation helps explain why one of the most significant branches of finance studies to emerge since the turn of millennium, the social studies of finance (SSF), has remained somewhat disconnected from these debates and discourses. SSF's focus on how technical devices and economic models generate knowledge for pricing financial instruments has sat uneasily alongside the macroeconomic and critical orientation of dominant stands of financialization studies, leading to the absence of shared language to incorporate its insights into the research agenda.

However, the groundwork for reconciling the fields has been laid by a new literature focused on knowledge, valuation and calculative practices. The most expansive attempt is Chiapello (2015, see also this volume). Chiapello argues that the spread of economizing quantifications generally takes the form of financialized valuation practices which have 'colonized' domains as varied as investment valuation, accounting standards, and banking supervision. Carruthers (2015) and Besedovsky (2017) understand the changing function of credit ratings similarly. While initially introduced as a commensuration tool to establish a descriptive ordinal ranking of the creditworthiness of corporations and states, the introduction of securitization in the 1970 s drove the credit-rating agencies to hire a raft of 'quants' whose probabilistic methods imbued the ratings with cardinal significance. The result was that market actors began to interpret the ratings as carrying implied probabilities of default, allowing the construction of instruments based on levels of risk adjusted yield (with results, in the case of mortgage-backed securities and collateralized debt obligations, which we discuss below). Lengwiler (2016) follows a parallel sets of developments in the insurance industry. There the increasing prominence of financial mathematics and attempts to integrate banking and insurance in the 1990s helped to reframe debates about mortality and longevity risks from a focus on the challenges of state provision to the needs of profitoriented investors. What these studies show is the importance of the epistemic 
shift brought about by the application of financial mathematics, changing fundamentally what finance does and what it is for.

As noted, this chapter follows this literature in understanding financialization as closely connected to financial mathematization. But it takes a step further. As well as seeking to avoid technological determinism by attending to the contingent regulatory decisions which advanced the trend, we also argue that whereas the aforementioned studies see financialization as the outcome of financial mathematization it is also valid to see financialization as describing the set of changes which transformed finance itself. While that might seem a tautological, or needlessly provocative move, it not without precedent. For example, it is close to Hardie's (2011) definition of financialization as the tradability of risk. In coining the definition, Hardie's aim is to furnish a metric that allows him to compare the borrowing capacity of emerging markets vis-à-vis the financialization of their government bond markets. Crucially, in this understanding of financialization it is securities markets themselves which can be more or less financialized depending upon their relative liquidity. Our aims are different, but Hardie's work serves to support our contention that there is insight to be gained by understanding the institutional, cognitive and technological transformation of the banking sector as a process of financialization enabled by risk management techniques.

The main advantage to understanding risk management techniques as driving a financialization of the banking sector is that it draws attention to the double-sided nature of the phenomenon. The rise of risk management is not, as the words might suggest, indicative of the financial sector becoming chronically risk-averse. The expansion of the use of derivatives from the early 1980s was as much about enabling new strategies for market speculation as it was about employing hedging strategies in portfolio management (Field, 2003). As a result, following the thread linking together BSM, VaR and CDO valuation shows how considering these techniques as just quantifying economizations glosses over a crucial dimension of 
the story with implications for the political economy of finance (cf. Çalışkan \& Callon, 2009; Chiapello, 2015). That is to say, our history shows that aim of risk management to place risk into circulation was equally about removing it offbalance-sheet for the purpose of minimizing regulatory capital. This understanding of risk management allows for reflection on the question of continuity and change in the post-crisis era. Scholars have noted, often despairingly, the obduracy of derivatives trading, risk-sensitive VaR calculations, and securitization in the financial sector, despite the well-known role of these techniques in contributing to the crisis (Admati, 2016; Lockwood, 2015; Stellinga \& Mügge, 2017; Underhill, 2015). Our history makes explicable the persistence of these calculative practices as well as allowing for a judicious evaluation of the extent of changes in the postcrisis era brought about by regulatory reforms.

\section{A history of risk management}

The conceptual foundations of risk management can be traced to modern portfolio theory (Field, 2003). Portfolio theory became a topic of scientific investigation in the 1950s and 60s, around the same time that risk emerged as an object of analysis in a broader context, including flood protection, food safety, and health (Power, 2007: 12). While in this broader context, risk as 'calculated uncertainty' facilitated the governance of hazards with limited resources, in finance it enabled the optimization of profit. The work of Harry Markowitz (1952) and others (Lintner, 1965; Sharpe, 1964; Treynor, 1961) established the idea that there is a trade-off between the risk and return of an investment that can be optimized through the construction of an efficient portfolio. The capital asset pricing model (CAPM) provides the theoretical rationale. It distinguishes between two aspects of financial risk: asset specific risk which can be mitigated by subsuming the asset in a diversified portfolio (and should therefore not be priced), and non-diversifiable risk or 'market risk', for which investors should be compensated with a risk premium (Treynor, 1961). 
The notion of a risk-return trade-off was further developed and operationalized with the publication of the Black-Scholes (1973) and Merton (1973) options pricing formula (BSM). Albeit at much lower volumes, derivative contracts had been traded for centuries using rule of thumb heuristics. The status of derivatives like commodity futures was for most of this history ambiguous: on the one hand, they could provide farmers with a means to insure their crops; on the other, they were often portrayed (and used) as a form of gambling. In this context, the BSM model greatly facilitated the proliferation of derivatives by providing a scientific exemplar for pricing derivatives that distinguished the practice from reckless gambling (MacKenzie \& Millo, 2003; de Goede, 2005: chapter 5). At the model's heart is the idea of a 'replicating portfolio'. It was possible, BSM suggested, to construct a continuously adjusted portfolio containing the underlying asset and 'risk-free' assets such as a cash deposit or treasury bonds that would replicate the pay-offs of the option contract itself. On the basis of the 'no-arbitrage' principle, which builds on the efficient market hypothesis (Fama, 1970) - no opportunity for riskless profit should exist since it would immediately be exploited and disappear - it follows that the price of the option must be equal to the cost of the replicating portfolio. The model therefore put the relative pricing of risk central in the valuation of financial assets (MacKenzie, 2006).

An initial application of the Black-Scholes model was on the trading floors of the Chicago Board Options Exchange. The equation entered the trading floor in 1975 via the use of pre-programmed calculators and the use of paper sheets with tables describing the relation between the volatility of the underlying stock, an option's strike price and its value (MacKenzie \& Millo, 2003). The use of these devices allowed traders to spot arbitrage opportunities such as opportunities to make a theoretically riskless profit by simultaneously taking a position in the option, its underlying asset and a 'risk-free' asset. As derivative strategies became more complex and the Black-Scholes equation was incorporated into daily trading 
activities, observed market prices and those predicted by the model gradually converged until the stock market crash in 1987 (MacKenzie, 2006: 174-177).

Another important use of the Black-Scholes model in the period before the crash was portfolio insurance. In the late 1970s, firms realized that the Black-Scholes model could be used to create 'synthetic put option' for market portfolios, setting a floor to how far the value of such a portfolio could drop (Leland \& Rubinstein, 1988; MacKenzie, 2006: 180). However, the dynamic hedging strategy required for the implementation of portfolio insurance forced investors to buy stock or index futures as market prices increased and sell stock or index futures as they decreased. When in October 1987 market price volatility increased this was exacerbated by a large number of institutional investors looking to sell - as prescribed by the portfolio insurance strategy - which eventually contributed to an unprecedented $22.6 \%$ 'nosedive' on 19 October. Analyses of the crisis conclude that markets did not only react to external events through the availability of new information, but had acquired their own 'irrational' internal dynamic caused, interalia, by strategies such as portfolio insurance and derivatives (Brady Commission, 1988). Yet the crash did not lead to the demise of risk management; it was a catalyst for its further development (Field, 2003).

In the years which followed, banks continued to invest in novel risk-management techniques. New metrics emerged that sought to turn risk into a manageable object, such as 'risk-adjusted return-on-capital' (James, 1996). Perhaps the most significant of these was value-at-risk (VaR), which in its simplest form is a representation of the distribution of expected returns of an investment and can therefore be considered a 'natural progression' from the mean-variance method of modern portfolio theory (Dowd, 1998: 19; Holton, 2002). While the metric remained impracticable for a long time due to the demanding computations it required, by the late 1980 s, once computer power had increased sufficiently, VaR eventually became the de facto standard for measuring risk in major banks and 
hedge funds. VaR allows various forms of risk, which in different departments were sometimes described in entirely different terms (often comprising ordinal rankings), to be represented, compared and aggregated in a single metric that can be understood intuitively (Kavanagh, 2003). With the introduction of VaR, capital allocation became a central problem of risk management: by establishing a connection between the riskiness of a portfolio and its rate of return, banks' management could compare the economic capital required for certain activities, allowing them to funnel funds into those activities with the best risk-return trade off (Holton, 2002; Kavanagh, 2003; Rosen, 2003) and to justify such decisions as rational decision-making (Lockwood, 2015).

Initially, quantitative risk management dealt primarily with market risk. However, during the 1990s other types of risk increasingly started to be analysed with methods consistent with the Black-Scholes model, which became an "exemplary problem solution" (MacKenzie, 2006: 139). Arbitrage-free pricing frameworks were developed for instruments such as credit and interest rate derivatives (Huault \& Rainelli-Le Montagner, 2009; Spears, 2014). Robert Merton (1974) had shown how you could analyse credit risk in corporate debt by modelling equity as a call option on a firm's assets. Similarly, interest rate modelling took off from the late-1980s onwards and culminated in the publication of the Heath-Jarrow-Morton (1992) framework, which provided a general no-arbitrage framework for modelling interest rate risk (Spears, 2014). Though some risks proved difficult to quantify, such as liquidity and operational risk, the Black-Scholes paradigm provided an intellectual resource that showed practitioners how various forms of uncertainty could be abstracted from financial markets and the economy more generally, and be turned into a 'manageable' and tradable object.

\section{The Basel Accords: From ignorance to enthusiasm}

In the early 1990s, regulators became increasingly aware of banks' own risk management systems. While regulators were initially reluctant to rely on these 
systems to determine banks' capital adequacy, they started to perceive these techniques as superior. The first international capital accord, Basel I, was agreed in 1988 and was the result of a long and difficult political process. Negotiations for the capital accord started in 1981, and were delegated to the Basel Committee on Banking Supervision (BCBS). As Charles Goodhart (2011) describes, the committee was tasked with creating a capital standard that would be implemented in each of the participating jurisdictions (whose supervisory practices diverged significantly) without having an effective internal mechanism to "impose its will on a recalcitrant member" (Goodhart, 2011: 548). An international capital standard was considered necessary to create a level playing field and undercut the competitive dynamics leading to banks' decreasing capitalisation. Although all national representatives recognized the importance of a shared standard, and indeed agreed that the capital adequacy ratio should to some extent reflect the riskiness' of banks' activities, agreeing on appropriate risk weightings proved difficult. Ultimately, however, the Basel Committee agreed on a standard that required banks to hold a minimum of $8 \%$ of capital against risk-weighted assets; assets were classified in one of five 'buckets' each of which was attributed a different weight. For example, while OECD sovereign bonds were assigned a $0 \%$ risk weighting, riskier assets such as corporate bonds and equities were weighted at 100\% (BCBS, 1988).

Basel I was considered an intermediate step towards a full capital standard regime, as it accounted only for credit risk. The text of the agreement contained an announcement that the Committee would also investigate possible methods for setting capital standards for interest rate and investment risk, an investigation that began in the mid-1980s (BCBS, 1988: 2). Eventually the BCBS published a proposed bucket-like methodology for the assessment of market risk in 1993, to which banks replied disapprovingly, claiming that the risk management systems they used internally to manage their trading book were more sophisticated (Goodhart, 2011: 247). As Goodhart notes, when possibilities for using these methods for regulatory capital were explored, BCBS working groups increasingly "found the work of the 
major international banks in assessing their own market risk to be impressive" (Goodhart, 2011: 249). The 1996 'Market Amendment' to the Basel I regime allowed banks to use their internal models to assess market risk. It used the VaR measure produced by these models as a basis for calculating capital requirements, which also included a factor to account for the quality of the models to encourage firms to improve them - an element that was enthusiastically supported by Robert Merton (Goodhart, 2011: 256).

The approach to regulatory capital adopted in the 1996 Market Risk Ammendement was further elaborated in the 2004 Basel II regime. Though Basel I had broadly achieved many of its initial aims, it also contained significant weaknesses (Kern, 2015), especially the treatment of credit risk. The risk buckets were regarded as "ad hoc and broad-brush, based on subjective (and political) judgment", and would lead to "serious distortions in bank asset portfolios" (Goodhart, 2011: 195). Assets within the same risk bucket appeared to have a significantly different risk profile from the perspective of risk management, which provided an opportunity for regulatory arbitrage (Lall, 2012).

To remedy these shortcomings, Basel II allowed banks to use internal models not only to calculate market risk, but also credit risk. The possibility to use an internal ratings based approach to credit risk meant that banks could use their own estimates of parameters such as the probability of default and the loss-givendefault to derive a distribution of 'default $V_{a} R^{\prime}$ - a weighted distribution of value at risk due to credit exposure - as a means of calculating their credit risk capital requirements. In doing so, banks would build on Merton's (1974) framework to treat the possibility of default as an option that could be valued using option pricing techniques. Moreover, the Basel accords sought actively to motivate banks to improve their internal methodology, promising reductions in regulatory capital (BCBS, 2001). From Basel I to Basel II, supervisors thus changed from being rather sceptical about the usefulness of internal models to becoming risk-management 
enthusiasts, who actively sought to improve banks' risk management systems by offering them rewards in the form of capital reductions for doing so. This was reflected in a broader ideological shift that took root in banking supervision. Chairman of the Fed at the time, Alan Greenspan, for instance, famously embraced risk management as a win-win solution allowing supervisors and firms to work together in enhancing the resilience of the financial system.

Risk management practices confronted regulators with both a challenge and an opportunity. The challenge arose from the fact that banks' use of risk management technology in combination with Basel I's 'crude' approach to asset weighting led to regulatory arbitrage (as explained above, under Basel I, assets that have similar risks but are classified differently might require different amounts of capital); but it also provided an opportunity to develop a seemingly rational, objective and scientific approach for determining capital adequacy standards that would 'depoliticize' capital regulation. It promised to overcome the limitations of the first Basel agreement, which had constituted a discrepancy between the regulatory and private risk knowledge categories thereby facilitating regulatory arbitrage (Lall, 2012; Major, 2012). Risk management also became a rhetorical device (Carruthers \& Espeland, 1991) that established trust in the supervisor-industry relations: both large investment banks and the supervisors representing the largest financial centres could live with a regulatory framework that relied on banks' internal risk management techniques (Lall, 2012; Ozgercin, 2012).

\section{Securitization as risk management}

The embedding of risk-capital techniques in regulation provided impetus for the development of additional risk management techniques. On the one hand, regulators came to see risk management as a useful tool to 'stabilize' financial markets. On the other, banks sought to develop increasingly complex riskmanagement constructions to reduce their regulatory capital, while at the same time retaining the profits arising from the new activities. Securitization offered a 
means to achieve this while at the same time appearing to satisfy regulators' demand for financial stability.

The modern practice of securitisation began in the 1970s with the U.S. government sponsored enterprises (GSEs), Freddie Mac and Fannie Mae, in an effort to expand credit in mortgage markets. House ownership has long been an important feature of the American economy and its realization unified both sides of the American political spectrum. In the 1960s, the Johnson administration perceived the traditional model of mortgage provision to be inadequate to cater to the housing needs of the baby boomer generation and to expand house ownership amongst lower income households. Mortgage-Backed Securities (MBSs) - a type of securitization that would later become part of a larger class of Asset-Backed Securities (ABSs) including, among other things, the income streams of automobile loans and credit cards - provided a technique to expand mortgage credit without needing to increase government expenditure or to keep the mortgages on the books of the GSEs (Fligstein \& Goldstein, 2012). In an ABS transaction, a bank moves assets from its balance sheet into a special purpose vehicle, which is then sliced into different tranches each bearing different levels of credit risk. The more 'senior' and 'safest' tranches of ABSs are typically funded by issuing bonds to investors; the junior tranche or tranches are typically funded by equity from the originating bank to provide an incentive for the bank to maintain adequate credit standards for the assets included in the ABS (Donnelly \& Embrechts, 2010; MacKenzie, 2011). Issuing ABSs allows a bank to pass off at least part of its credit risk onto investors who are rewarded, in turn, with a risk premium. Moreover, the ABS transaction frees up capital on the bank's balance sheet, allowing it to take on new credit risk by underwriting new loans. Through this mechanism, the creation of MBSs was considered a useful tool for aggregating and diffusing geographically concentrated risk and to free up the balance sheet of banks to enhance their ability to underwrite new mortgages (Aalbers, 2008; Fligstein \& Goldstein, 2012; MacKenzie, 2011; Poon, 2009). 
Credit risk evaluation played a crucial role in the construction and management of ABSs. The modelling of credit risk, in which rating agencies such as Standard \& Poor's and Moody's took a leading role, is necessary so that buyers of ABSs can judge whether the size of the 'risk premium' makes it worthwhile to engage in a transaction. The importance of credit ratings meant that the securities and "knowledge of the securities" were "coproduced": the ABS tranches were designed specifically to achieve certain ratings (MacKenzie, 2011: 1795). The evaluation of an $A B S$ requires credit rating agencies and banks to estimate the probability of default, and, in the case of a MBS, the risk of prepayment of individual loans in the pool as well as the correlation of risks across different assets - a complicated problem that in the case of early ABSs was dealt with implicitly and procedurally rather than mathematically (MacKenzie, 2011: 1796-97, 1802-04). For example, credit rating agencies would apply penalties to a security's rating if they thought that the included mortgages were too geographically concentrated.

From the 1990s onwards, securitisation became an important activity of banks' derivatives departments, who sought to construct Collateralized Debt Obligations (CDOs) from corporate debt and referred to these constructions as credit derivatives rather than securities (MacKenzie, 2011: 1803-04). Similar to ABSs, the main purpose for banks to construct big balance-sheet CDOs was "to shed credit risk from their portfolios of loans to corporations and to reduce the capital reserves that regulators insisted they hold in respect to that lending" (MacKenzie, 2011: 1800). Regulators were aware of banks moving assets off balance sheet towards unregulated entities, but allowed them to do so at the perceived benefit of domestic banks' international competitive position (Thiemann, 2014). The shifting organisational locus of securitisation that came with CDOs, however, would have important implications for how these assets were evaluated. Professionals at banks' derivatives departments had a proclivity for adopting mathematical solutions rather than procedural ones (MacKenzie \& Spears, 2014). Hence, banks 
adopted the Gaussian copula family of models to quantify the correlation between the probabilities of default on pools of assets in a manner loosely analogous to a Black-Scholes approach to pricing and measuring risk. The use of Gaussian copula models became widespread with the publication of JP Morgan's CreditMetrics risk management software in 1997, and would in subsequent years also be adopted by credit rating agencies (Donnelly \& Embrechts, 2010; MacKenzie, 2011; MacKenzie \& Spears, 2014).

Similar to ABSs, CDOs not only allowed banks to move their assets off balance sheet, but also provided a profitable arbitrage opportunity. The risk premium demanded by investors to share their credit risk burden was often sufficiently low to boost banks' profits without taking on additional risk. Annual issuance of CDOs grew explosively from less than $\$ 70 b n$ in 2000 to more than $\$ 500 b n$ at the market's peak year in 2006 (SIFMA, 2016). Not only the amount, but also the structure of CDOs changed rapidly. In the years leading up to the global financial crisis, more than half of the debt underpinning CDOs did not consist of corporate bonds but rather of ABSs. Differences between how ABSs were valued and the quantitative approaches to the valuation of CDOs had led to a "fatally attractive arbitrage opportunity", on which banks sought to capitalize by constructing ABSCDOs (MacKenzie, 2011: 1778). Thus, the use of quantitative risk management techniques, embedded in systems such as JP Morgan's RiskMetrics, enabled banks to profit from various forms of arbitrage, and facilitated large-scale removal of various forms of consumer and corporate credit from banks' balance sheets, where they were subject to capital regulation, to off-balance-sheet entities, where they were not. In combination with derivatives-enabled portfolio management and internal VaR models for calculating regulatory capital, securitization brought to completion the financialized financial system - a system of baroque complexity grounded in decades of developments in mathematical financial theory. 
However, the 2007-9 crisis revealed the fragility of this system. The large concentrations of risk that had been put into circulation and hidden from regulatory scrutiny came home to roost. In late 2006 and continuing in 2007, U.S. house prices began to fall. Two large subprime mortgage originators declared bankruptcy and credit rating agencies downgraded MBSs. In August, these downgrades triggered the first interbank panic. Concerns about the solvency of counterparties and the liquidity of bonds led to increasing collateral demands in short-term debt markets, eroding banks' equity capital buffers (Gorton \& Metrick, 2012). The problem was compounded by special purpose vehicles incurring heavy losses. When Lehman Brothers filed for bankruptcy in September 2008, U.S. authorities, fearing the collapse of the entire financial system, made unprecedented interventions to keep it afloat. The GSEs were brought into the conservatorship of the federal government. The Federal Reserve also lent $\$ 85$ billion to the insurer AIG, who had been prolific in writing credit default swaps on now failing securitized products. Yet those interventions would pale in comparison to the Troubled Asset Relief Programme, which authorized U.S. authorities to spend up to $\$ 700$ billion purchasing predominantly securitized assets. And so the story goes on, morphing from a banking crisis into a potentially catastrophic sovereign debt crisis until the announcement of the Outright Monetary Transactions programme by the European Central Bank in August 2012 (Braun, 2015: 420).

The quantitative techniques traced out in this chapter contributed to the crisis in three main ways. First, derivatives pricing through BSM, VaR modelling of market and credit risk, and mathematical CDO valuation, are predicated on the idea that risk is a manageable object that can be sliced, diced, and traded with precision. To achieve such precision, they rely on statistical inferences based on past market prices. When markets began to behave in unexpected ways, the promise of taming uncertainty and converting it into a measurable risk proved illusory. Second, these techniques, once credited with distributing risk safely throughout the financial 
system, had the unintended consequence of making it hard for practitioners to know where risks were concentrated in the event of a crisis. As Gorton (2010) and Ricks (2016) argue, when MBSs were downgraded in early 2007 the result was a series of interbank panics bearing the hallmarks of the banking panics experienced before the introduction of deposit insurance in the U.S. Banking Act of 1933. Since firms did not know who among their counterparties were potentially insolvent, and fearing precipitous declines in their value of their collateral, liquidity dried up and a damaging credit crunch ensued. It is these opaque circulations of risk which have come to be distilled into the rubrics of 'systemic risk' and 'interconnectedness' prevalent after the crisis. Third, from its inception risk management was motivated at least in part by economizing on regulatory capital. The risk sensitive VaR metric allowed banks to reduce their capital buffers and increase their leverage. Basel II pivoted on the assumption of an incentive alignment between the stability-seeking objectives of public authorities and the profit-maximizing objectives of private actors. That was reflected in failures of bank supervisors to sufficiently monitor how banks' internal models were being used to calculate their regulatory capital. Finally, the use of off-balance-sheet special purpose entities to conduct securitization and manufacture CDOs, while not grounded in financial theory, drew support from these techniques' affinities to established risk management practices.

\section{Conclusion: post-crisis denouement}

This chapter has argued that the financialization of the banking sector involved cumulative developments in quantitative techniques unified under the notion of risk management. Although contributing to a new literature on focused on the role of calculative practices in the financialization process, we have sought to avoid technological determinism by emphasising the importance of the contingent regulatory decisions which contributed to the shift. It is possible that many of the later techniques would still have been employed in the absence of the regulatory seal of approval granted to risk management by the BCBS from the 1990s onwards. 
But it is unlikely that the banking sector would have been so profoundly transformed, or financial stability risks so amplified.

Of course, when the house of cards came tumbling during the financial crisis many of the assumptions of risk management were called into question, at least for a time. Among the most authoritative accounts are by the U.S. Financial Crisis Inquiry Commission (FCIC, 2011) and the U.K.'s Turner Review (FSA, 2009). Both see derivatives, VaR modelling, and securitization as transforming finance from the 1970s onwards into a newly complex and unstable form. The Turner Review goes so far as to identify the model of securitized credit intermediation as have an "inherent" tendency to promote systemic risk (FSA, 2009: 43). It is therefore surprising, given the acknowledged failure of the financialized banking model, that so little seems to have changed in the years since. Some figures are instructive. According to data by the Bank for International Settlements, although there has been a marked shift from over-the-counter to exchange-traded derivatives in the post-crisis era, there has been no overall reduction in the notional market value of derivatives since 2009 (BIS, 2017). There are similar continuities with securitization. While issuance in Europe never recovered to its pre-crisis peak, in the U.S. securitization issuance stood at \$1.4 trillion in 2009 and by 2016 increased to \$1.8 trillion - a trajectory of steady growth, albeit with some ups and downs along the way (AFME, 2017: 6).

At the same time, if the financialized banking sector is understood as being as much a regulatory construct as set of calculative practices, then characterising the post-crisis period is more difficult. As is well-known, in the aftermath of the crisis the big idea for responding to this new financial world is macroprudential regulation: an acknowledgement that neither the incentives of financial institutions nor a regulatory focus on individual firms would be sufficient to prevent another crisis (Baker, 2013; Barwell, 2013; Hanson, Kashyap, \& Stein, 2011). Instead, it would be necessary to empower regulators with the means to know and 
control the financial system as a whole and implement counter-cyclical policies to lean against the growth of credit and leverage. Before and immediately after the crisis, the tools that would provide regulators with the knowledge to perform this function simply did not exist. Yet in the years since, the development of metrics for measuring systemic risk and agent-based modelling of the financial system have taken regulators ever further away from standard neoclassical theories in the area of financial stability (Bookstaber, 2017). Indeed, with macroprudential policies rejecting core tenets of the efficient markets hypothesis and the idea of rational expectations, some scholars have gone so far as to portray them as a bold challenge to neoliberalism (Baker \& Widmaier, 2015). More recently, however, a sober, even sombre, appraisal of the achievements of the policy-shift has emerged. As mooted interventionist policies to smooth the credit cycle have given way to the notion of bolstering resilience and emphasis on simply improving bank capitalization, commentators once enthused by regulators' counter-cyclical ambitions have found fault in practically the entire sweep of post-crisis regulation as insufficiently counter-cyclical (Underhill, 2015).

How far has post-crisis regulation deviated from its pre-crisis trajectory? There is no way to settle the question definitively. Depending on the aspect of regulation focused on and one's evaluative standard, different answers will be returned. Those hoping to see a radical, structural departure from the status quo ante will inevitably be disappointed, whereas those attuned to incremental sociotechnical advances are likely to see a somewhat more promising picture. What is clear is that on the terms proposed in this chapter there has been no reversal of the banking sector's financialization. There has been no retreat from risk management as the overarching paradigm of financial practices and their supervision. Yet with a loss of faith in the ability of banks to manage their risk prudently, that now puts regulators in a paradoxical position. In the aftermath of the crisis, regulators want to see and control this world of risk management; they want to control that which was 
designed to evade control. Whether or not the ambition will prove tenable remains to be seen.

\section{References}

Aalbers, M. B. (2008). The Financialization of Home and the Mortgage Market Crisis. Competition \& Change, 12(2), 148-166.

Admati, A. R. (2016). The Missed Opportunity and Challenge of Capital Regulation. National Institute Economic Review, 235(1), R4-R14.

AFME, (Association of Financial Markets in Europe). (2017). Securitisation Data Report: European Structured Finance: Q1: 2017. London.

Alvarez, I. (2015). Financialization, non-financial corporations and income inequality: the case of France. Socio-Economic Review, 13(3), 449-475.

Arrighi, G. (1994). The Long Twentieth Century: Money, Power, and the Origins of our Times. London: Verso.

Baker, A. (2013). The New Political Economy of the Macroprudential Ideational Shift. New Political Economy, 18(1), 112-139.

Baker, A., \& Widmaier, W. (2015). Macroprudential Ideas and Contested Social Purpose: A Response to Terrence Casey. The British Journal of Politics \& International Relations, 17(2), 371-380.

Barwell, R. (2013). Macroprudential policy taming the wild gyrations of credit flows, debt stocks and asset prices. Basingstoke, Palgrave Macmillan.

BCBS. (1988). International Convergence of Capital Measurement and Capital Standards, (July). Bank for International Settlements: Basel, Switzerland. 
BCBS. (2001). The Internal Ratings-Based Approach. Bank for International Settlements: Basel, Switzerland.

Besedovsky, N. (2017). Financialization as calculative practice: the rise of structured finance and the cultural and calculative transformation of credit rating agencies. Socio-Economic Review, 16(1), 61-84.

BIS, (Bank for International Settlements). (2017). Statistical release: OTC derivatives statistics at end-June 2017. Basel, Switzerland.

Bookstaber, R. (2017). The End of Theory: Financial Crises, the Failure of Economics, and the Sweep of Human Interaction. Princeton, NJ: Princeton University Press.

Brady Commission. (1988). Report of the Presidential Task Force on Market Mechanisms. Washington, D.C.

Braun, B. (2015). Preparedness, Crisis Management and Policy Change: The Euro Area at the Critical Juncture of 2008-2013. The British Journal of Politics and International Relations, 17(3), 419-441.

Çalışkan, K., \& Callon, M. (2009). Economization, part 1: shifting attention from the economy towards processes of economization. Economy and Society, 38(3), 369-398.

Carruthers, B. G. (2015). Financialization and the institutional foundations of the new capitalism. Socio-Economic Review, 13(2), 379-398. 
Carruthers, B. G., \& Espeland, W. N. (1991). Accounting for Rationality: DoubleEntry Bookkeeping and the Rhetoric of Economic Rationality. American Journal of Sociology, 97(1), 31-69.

Chiapello, E. (2015). Financialisation of Valuation. Human Studies, 38(1), 13-35.

Christophers, B. (2015). The limits to financialization. Dialogues in Human

Geography, 5(2), 183-200.

Donnelly, C., \& Embrechts, P. (2010). The Devil is in the Tails: Actuarial Mathematics and the Subprime Mortgage Crisis. ASTIN Bulletin, 4O(1), 1-33.

Dowd, K. (1998). Beyond Value at Risk: The New Science of Risk Management. Chichester, UK: John Wiley \& Sons.

Epstein, G. (2006). Introduction. In Financialization and the World Economy (pp. 316). Cheltenham, UK and Northampton, USA: Edward Elgar.

Fama, E. F. (1970). Efficient Capital Markets: A Review of Theory and Empirical Work. Journal of Finance, 25(2), 383-417.

FCIC. (2011). Financial Crisis Inquiry Report: Final Report of the National Commission on the Causes of the Financial and Economic Crisis in the United States. Washington, D.C.

Field, P. (2003). Modern risk management: a history. London: Risk Books.

Fligstein, N., \& Goldstein, A. (2012). A Long Strange Trip: The State and Mortgage Securitization, 1968-2010. In K. Knorr Cetina \& A. Preda (Eds.), The Oxford Handbook of the Sociology of Finance (pp. 339-356). Oxford: Oxford University Press. 
Froud, J., Haslam, C., Johal, S., \& Williams, K. (2000). Shareholder value and Financialization: consultancy promises, management moves. Economy and Society, 29(1), 80-110.

FSA. (2009). The Turner Review: A Regulatory Response to the Global Banking Crisis. London.

Gabor, D. (2016). The (impossible) repo trinity: the political economy of repo markets. Review of International Political Economy, 23(6), 1-34.

Gabor, D., \& Ban, C. (2016). Banking on Bonds: The New Links Between States and Markets. JCMS: Journal of Common Market Studies, 54(3), 617-635.

Goodhart, C. (2011). The Basel Committee on Banking Supervision: A History of the Early Years 1974-1997. Cambridge University Press.

Gorton, G. B. (2010). Slapped by the Invisible Hand: The Panic of 2007. Cary, U.S.: Oxford University Press.

Gorton, G., \& Metrick, A. (2012). Securitized banking and the run on repo. Journal of Financial Economics, 104(3), 425-451.

Hanson, S. G., Kashyap, A. K., \& Stein, J. C. (2011). A Macroprudential Approach to Financial Regulation. The Journal of Economic Perspectives, 25(1), 3-28.

Hardie, I. (2011). How much can governments borrow? Financialization and emerging markets government borrowing capacity. Review of International Political Economy, 18(2), 141-167. 
Hardie, I., \& Howarth, D. (Eds.). (2013). Market-Based Banking and the International Financial Crisis - Oxford Scholarship. Oxford: Oxford University Press.

Heath, B. Y. D., Jarrow, R., \& Morton, A. (1992). Bond Pricing and the Term Structure of Interest Rates: A New Methodology for Contingent Claims Valuation. Econometrica, 60(1), 77-105.

Holton, G. A. (2002). History of Value-at-Risk: 1922-1998. Working paper. Available at https://econpapers.repec.org/paper/wpawuwpmh/0207001.htm.

Huault, I., \& Rainelli-Le Montagner, H. (2009). Market Shaping as an Answer to Ambiguities: The Case of Credit Derivatives. Organization Studies, 30(5), 549-575.

Kavanagh, B. (2003). A Retrospective Look at Market Risk. In P. Field (Ed.), Modern Risk Management: A History (pp. 251-260). London: Risk Books.

Kern, A. (2015). The Role of Capital in Supporting Banking Stability. In N. Moloney, E. Ferran, \& J. Payne (Eds.), The Oxford Handbook of Financial Regulation (pp. 334-363). Oxford: Oxford University Press.

Lall, R. (2012). From failure to failure: The politics of international banking regulation. Review of International Political Economy, 19(4), 609-638. Lazonick, W., \& O’Sullivan, M. (2000). Maximizing shareholder value: a new ideology for corporate governance. Economy and Society, 29(1), 13-35. 
Lee, R., Clark, G. L., Pollard, J., \& Leyshon, A. (2009). The remit of financial geography-before and after the crisis. Journal of Economic Geography, 9(5), 723-747.

Leland, H., \& Rubinstein, M. (1988). The Evolution of Portfolio Insurance. In D. Luskin (Ed.), Dynamic Hedging: A Guide to Portfolio Insurance. John Wiley \& Sons.

Lengwiler, M. (2016). Risky Calculations: Financial Mathematics and Securitization since the 1970s. Historical Social Research/Historische Sozialforschung, 41(2), 258-279.

Lintner, J. (1965). Security prices, riks, and mazimal gains from diversification. The Journal of Finance, 20(4), 587-615.

LiPuma, E. (2017). The Social Dimensions of Black Scholes. Unpublished Manuscript. Lockwood, E. (2015). Predicting the unpredictable: Value-at-risk, performativity, and the politics of financial uncertainty. Review of International Political Economy, 22(4), 719-756.

MacKenzie, D. A. (2006). An engine, not a camera: How financial models shape markets. Cambridge, MA: MIT Press.

MacKenzie, D. A. (2011). The Credit Crisis as a Problem in the Sociology of Knowledge. American Journal of Sociology, 116(6), 1778-1841.

MacKenzie, D. A., \& Millo, Y. (2003). Constructing a Market, Performing Theory: The Historical Sociology of a Financial Derivatives Exchange. American Journal of Sociology, 109(1), 107-145. 
MacKenzie, D. A., \& Spears, T. (2014). "The formula that killed Wall Street": The Gaussian copula and modelling practices in investment banking. Social Studies of Science, 44(3), 393-417.

Major, A. (2012). Neoliberalism and the new international financial architecture. Review of International Political Economy, 19(4), 536-561.

Markowitz, H. (1952). Portfolio selection. The Journal of Finance, 7(1), 77-91.

Merton, R. C. (1974). On the pricing of corporate debt: the risk structure of interest rates. The Journal of Finance, 29(2), 449-470.

Ozgercin, K. (2012). Seeing like the BIS on Capital Rules: Institutionalising Selfregulation in Global Finance. New Political Economy, 17(1), 97-116.

Poon, M. (2009). From new deal institutions to capital markets: Commercial consumer risk scores and the making of subprime mortgage finance. Accounting, Organizations and Society, 34(5), 654-674.

Poovey, M. (2015). On 'the limits to financialization.' Dialogues in Human Geography, 5(2), 220-224.

Power, M. (2007). Organized uncertainty: designing a world of risk management. Oxford: Oxford University Press.

Ricks, M. (2016). The Money Problem: Rethinking Financial Regulation. Chicago and London: University of Chicago Press.

Rosen, D. (2003). The Development of Risk Management Software. In P. Field (Ed.), Modern Risk Management: A History (pp. 135-150). London: Risk Books. 
Sharpe, W. F. (1964). Capital Asset Prices: A Theory of Market Equilibrium under Conditions of Risk. The Journal of Finance, 19(3), 425-442.

Spears, T. (2014). Engineering Value, Engineering Risk: What Derivatives Quants Know and What Their Models Do. Edinburgh.

Stellinga, B., \& Mügge, D. (2017). The regulator's conundrum. How market reflexivity limits fundamental financial reform. Review of International Political Economy, 24(3), 393-423.

Stockhammer, E. (2004). Financialisation and the slowdown of accumulation. Cambridge Journal of Economics, 28(5), 719-741.

Thiemann, M. (2014). In the Shadow of Basel: How Competitive Politics Bred the Crisis. Review of International Political Economy, 21(6), 1203-1239.

Treynor, J. L. (1961). Toward a theory of market value of risky assets. Unpublished Manuscript.

Tridico, P., \& Pariboni, R. (2017). Inequality, financialization, and economic decline. Journal of Post Keynesian Economics, 41(2), 236-259.

Underhill, G. R. D. (2015). The Emerging Post-Crisis Financial Architecture: The Path-Dependency of Ideational Adverse Selection. The British Journal of Politics and International Relations, 17(3), 461-493.

Venugopal, R. (2015). Neoliberalism as concept. Economy and Society, 44(2), 165187. 